\title{
Factors Affecting Sleep Quality of Breast Cancer Patients with Chemotherapy
}

\author{
Diyanah Syolihan Rinjani Putri ${ }^{1}$, Sri Nabawiyati Nurul Makiyah ${ }^{2 *}$ \\ ${ }^{1}$ Nursing Profession Study Program, Faculty of Health, Universitas Kusuma Husada Surakarta, Banjarsari, Surakarta, \\ Indonesia; ${ }^{2}$ Department of Histology, Immunology and Biology, School of Medicine, Faculty of Medicine and Health Sciences, \\ Universitas Muhammadiyah Yogyakarta Jalan Brawijaya, Tamantirto, Kasihan, Bantul, DI, Indonesia
}

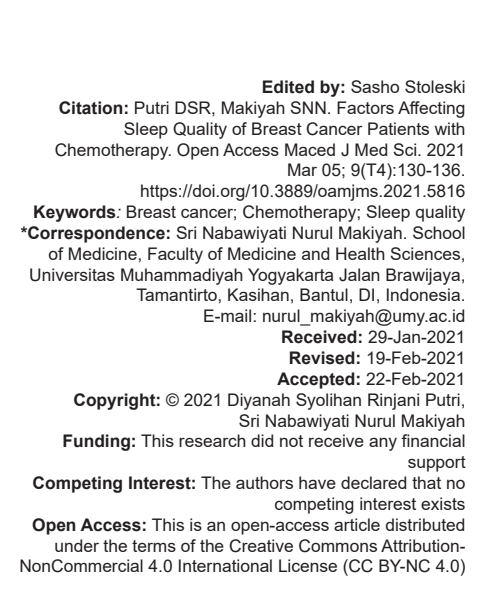

\section{Introduction}

Carcinoma mammae, or what we commonly refer to as breast cancer, is a malignant tumor that grows in breast tissue. Patients with breast cancer can experience various physical, psychological changes (such as levels of depression and anxiety), social functions, and sexual and daily activities. This will affect the quality of life or quality of life sufferers [1]. Besides, breast cancer is the growth of abnormal cells that are not controlled in the breast tissue that can cause metastasis (spread) to other organs, especially in organs around the breast [2].

Breast cancer increased year by year. American Cancer Society (ACS) (2017) [3] estimates that there are 63.410 new cases of breast cancer in situ, 252,710 invasive breast cancer on woman and 2.470 on men, unfortunately around 40.610 women and 460 men were estimated have died. Based on the World Health Organization data, breast cancer is mostly found in women. There are 1.5 million women who suffer from breast cancer each year. Breast cancer became the second large cancer in women. Globocan International Agency Research on Cancer (IARC) reported that there were 58.256 new cases of breast cancer in 2018.

There are various ways to treat cancer patients, including surgery, chemotherapy, and also radiotherapy [4], but the most used is chemotherapy. Chemotherapy is a therapy which increments breast cancer patients [5]. The side effects of chemotherapy include anorexia, fatigue, insomnia, hair loss, or sleep disorders besides giving birth to negative emotions such as anxiety and depression [5].

The research which was conducted out by Wesselius et al. [6] and The research which was conducted out by Bukit (2005) [6] showed that there are some factors in sleep quality effects, namely environment and psychology. Environmental factors which can influence patients' noise of hospital staff, noise of medical instruments, bed or pillow, lights, transfer to new room, and alarm clock. Psychology 
factors influence patients' reasons include pain, anxiety, and worrying about illness. This is in line with Alifiyanti et al. [7] at RSUP Dr. Hasan Sadikin (RSHS) Bandung which used Pittsburgh Sleep Quality Index (PSQI). Sleep quality is stated as good when the total score is $\leq 5$. It can be concluded that the total score, which is more than that is classified as poor.

Sleep impediment can cause sleep quality of breast cancer patients who are undergoing chemotherapy. It is supported by 115 patients experience sleep impediment after chemotherapy [8]; Tian et al. [9] stated that cancer patients before getting therapy had a sleep disorder $52.6 \%$ and after getting chemotherapy sleep disorders increased to $64.5 \%$. Cancer patients, after going through chemotherapy, have a long time to start sleeping and often wake up in the middle of the night from 21 times to 29 times [10]. At RSUD Djojonegoro Temanggung, the number of cancer patients undergoing chemotherapy in November 2017 was 139 people, while there were 58 patients diagnosed with breast cancer.

This study aimed to examine the factors that influence the sleep quality of breast cancer patients undergoing chemotherapy at Djojonegoro Temanggung Hospital.

\section{Methods}

This research used observational research with cross-sectional design. The population of this study was all breast cancer patients, with the total of 56 people who underwent chemotherapy at Djojonegoro Regional Hospital in Temenggung. Purposive sampling was used in this study. The standard of inclusion in this study is that breast cancer respondents do not suffer from hearing loss, can read and write, aged more than 18 years, undergo chemotherapy once a week, get adjuvant chemotherapy (chemotherapy after getting radical surgery), the female patients undergoing chemotherapy who have poor sleep quality are found to be in the same house with the respondents. The exclusion standard is that the respondent has an allergy/ sensitivity to sounds such as epilepsy. The number of respondents who met the inclusion and exclusion criteria was 26 people.

This research was conducted in May-June 2018 in the chemotherapy room at Djojonegoro Temanggung Hospital. The tool for assessing sleep quality is the PSQI questionnaire, PSQI scores 0-21, showed that sleep quality is good when $<5$, and it is said to be poor sleep quality $>5$. The sample of the study was 26 breast cancer patients who took chemotherapy at Djojonegoro Regional Hospital in Temanggung, Central Java. Specific records of respondents included data on age, marital status, education, occupation, income, home environment, when was diagnosed with breast cancer, length of time undergoing chemotherapy, chemotherapy to what location, mastectomy location, living with whom, accompanying diseases, consumption of sleeping pills, lighting during sleep, and sleep quality. Sleep quality was measured using PSQI. Data were tested for validity and analyzed with descriptive statistics. Analysis of the data used to assess matters relating to sleep quality in breast cancer patients is the Spearman Rank test and the Pearson product-moment correlation test.

\section{Results}

This study aims to examine the things that have an impact on the sleep quality of breast cancer patients who are taking chemotherapy. The results of research on the characteristics of breast cancer patient respondents undergoing chemotherapy include age, marital status, education, employment, and income can be seen in Table 1.

Table 1: Respondent characteristics breast cancer patients undergoing chemotherapy $(n=26)$

\begin{tabular}{lll}
\hline Characteristic & F & $\%$ \\
\hline Age $(x \pm$ SD) & $50.08 \pm 7.31$ & \\
Marital status & & \\
$\quad$ Married & 21 & 80.76 \\
$\quad$ Divorce & 5 & 19.24 \\
Education & 1 & 3.85 \\
$\quad$ No education & 11 & 42.31 \\
$\quad$ Elementary & 7 & 26.92 \\
Junior high & 4 & 15.38 \\
$\quad$ Senior high & 3 & 11.54 \\
$\quad$ College & & \\
Profession & 10 & 38.46 \\
Work & 16 & 61.54 \\
Does not work & & 61.54 \\
Income & 16 & 3.85 \\
$\quad$ Rp. 0 & 1 & 15.38 \\
<Rp. 500.000 & 4 & 7.69 \\
Rp. 500.000-Rp. 1.000.000 & 2 & 11.54 \\
Rp. 1.000.000-Rp. 1.500.000 & 3 & \\
>Rp. 1.500.000 & & \\
\hline
\end{tabular}

Based on Table 1, breast cancer patients undergoing chemotherapy aged $50.08 \pm 7.31$ years, the majority of marital status is married as many as $80.76 \%$, the majority of education is elementary school as many as $42.31 \%$, the majority does not work as many as $61.54 \%$ so that the majority of his income is Rp. 0, - as many as $61.54 \%$.

The data of breast cancer respondents who underwent chemotherapy, which includes the home environment, the length of time diagnosed with breast cancer, the length of time undergoing chemotherapy, the chemotherapy to what extent, and the location of mastectomy can be seen in Table 2 .

Based on Table 2, the majority of breast cancer patients undergoing chemotherapy had a residence in a rice field environment of $42.31 \%$, the majority of those diagnosed with breast cancer less than 1 year were $69.23 \%$, the length of time undergoing chemotherapy, the majority were less than 1 year for $96.15 \%$, and on average underwent $7.23 \pm 4.80$ chemotherapy, and the majority of mastectomy sites in the left breast were $80.77 \%$. 
Table 2: Personal data of breast cancer patients undergoing chemotherapy $(n=26)$

\begin{tabular}{lll}
\hline Personal data & F & $\%$ \\
\hline Home environment & & \\
$\quad$ Village & 8 & 30.77 \\
$\quad$ Carriageway & 3 & 11.54 \\
$\quad$ Rice fields & 11 & 42.31 \\
$\quad$ Housing & 4 & 15.38 \\
Long diagnosed with cancer in years & & \\
$\quad<1$ & 18 & 69.23 \\
$1-3$ & 5 & 19.23 \\
$>3$ & 3 & 11.54 \\
Time undergoing chemotherapy in year & & 96.15 \\
$\quad<1$ & 25 & 3.85 \\
$1-3$ & 1 & \\
Chemotherapy & $7.23 \pm 4.80$ & 19.23 \\
Location of mastectomy & & 80.77 \\
$\quad$ Right & 5 & \\
$\quad$ Left & 21 & \\
\hline
\end{tabular}

Table 3 shows data on sleep quality and the factors that influence it on breast cancer patients undergoing chemotherapy, which include sleep quality, and lighting during sleep, consumption of sleeping pills, comorbidities, and who lives with whom.

Table 3: Data on sleep quality for breast cancer patients undergoing chemotherapy $(n=26)$

\begin{tabular}{lll}
\hline Sleep quality data & F & $\%$ \\
\hline Sleep quality & $10.96 \pm 3.13$ & \\
$\quad$ Good & 0 & 0 \\
Poor & 26 & 100 \\
Light on while sleeping & & \\
Yes & 17 & 65.38 \\
$\quad$ No & 9 & 34.62 \\
Consumption of sleeping pills & 0 & 0 \\
Yes & 26 & 100 \\
No & & \\
Comorbid & 5 & 19.23 \\
Yes & 21 & 80.77 \\
No & & \\
Stay at home with & 16 & 61.54 \\
$\quad$ Main family & 6 & 23.07 \\
Children & 3 & 11.54 \\
Family & 1 & 3.85 \\
$\quad$ Alone & & \\
\hline
\end{tabular}

Based on Table 3, all had poor sleep quality $(100 \%)$, all breast cancer patients undergoing chemotherapy, the majority sleeping with lights on was as much as $65.38 \%$, did not take sleeping pills as many as 21 people $(100 \%)$, the majority not having comorbidities was as many as 21 people $(80.77 \%)$, and the majority living with their families was as many as 16 people $(61.54 \%)$.

The physiological status of breast cancer patients undergoing chemotherapy, that is, blood pressure can be seen in Table 4.

Table 4: Blood pressure data for breast cancer patients undergoing chemotherapy $(n=26)$

\begin{tabular}{ll}
\hline Physiology status & Mean \pm SD \\
\hline Blood pressure & $129 \pm 20.62$ \\
Systole & $84.00 \pm 14.75$ \\
Diastole & \\
\hline
\end{tabular}

Based on Table 4, the physiological status of breast cancer patients undergoing chemotherapy shows that systolic blood pressure is $129 \pm 20.62$ and diastolic blood pressure is $84.00 \pm 14.75$.

\section{Discussion}

The level of education influences behavior and produces a lot of changes, especially knowledge in the health field. The higher the level of one's education, the higher the level of knowledge [11]

In this study, respondents' level of education is elementary school; therefore, they have inadequate knowledge related to cancer prevention and treatment of sleep disorders. In research [12], there is a relationship between the level of education with the level of knowledge of women about breast cancer. This shows that there is a relationship between the level of education and the level of knowledge of women about breast cancer.

Cancer management using chemotherapy in the early stages of treating chemotherapy as the main element that forms poor sleep quality or sleep disturbance [10]. Sleep disorders that occur due to chemotherapy are in the latent component of sleeping and waking up at night. Chemotherapy causes a person needs 34.8 min to start sleeping and waking up as many as 21-29 times at night [11]. This results in a short amount of time for patients to sleep and a poor quality sleep [13].

The physiological status of breast cancer patients undergoing chemotherapy. It is cancer management using chemotherapy in the early stages of treating chemotherapy as the main element that forms poor sleep quality or sleep disturbance [10]. Sleep disorders that occur due to chemotherapy are in the latent component of sleeping and waking up at night. Chemotherapy causes a person needs $34.8 \mathrm{~min}$ to start sleeping and waking up as many as 21-29 times at night [11]. This results in a short amount of time for patients to sleep and a poor quality sleep [13]

Sleep can form restorative functions, namely the functions of restoring tired body parts, stimulating growth, and maintaining a healthy body. In the process of sleep, if given enough time and the right environment, it will produce extraordinary power. Furthermore, sleep can rejuvenate, restore, and provide energy for the body and brain, and good sleep can add body's resistance from disease [14]. Based on the research from Ummah let al. [15], sleep is believed to restore energy because sleep provides time for repairing and healing the body's system for the next period of being awake. The use of dimmed or turned off lights during sleep can have a positive effect on awake time or alertness being shorter, and making sleepiness faster [16]. Someone who is exposed to long duration of light at night will get sleep delays [17].

According to ACS, the incident rate in most cancers occurs at the age of 50-69 years, while in Indonesia, the incidence is at the age of 45-54 years [18]. It is in line with Nurzallah et al. [19] stating that the risk of breast cancer development rises as the age increases. In a study conducted by Sihombing (2014), of 1803 people who took the ultrasonography, there were 61 with breast tumors (3.4\%), while those without tumors were 1742 (96.9\%). Based on age groups, it is 
known that more than half of the respondents in both case group $(68.9 \%)$ and control group $(96.7 \%)$ were at the age of 40 years or more.

Patients who have recently been diagnosed with cancer and undergo chemotherapy treatment and continue to experience sleep disturbances because they often wake up in the middle of the night to urinate in the bathroom, anxious, cannot sleep before or after waking up in the middle of the night [20]. Moreover, the patients who have repeatedly received chemotherapy are increasingly at risk of experiencing sleep disorders and insomnia, so they need to be given with therapy to deal with sleep disorders [10].

Family support is an important factor for a person in the face of health problems that may play a role in the function of health care for family members to achieve optimal health (Sukriswati, 2016). Family support will bring a sense of security, comfort, and hope for patients so that it can create a calm that can make it easier for patients to fulfill their sleep needs [21].

George's research results (2016) described the sleep quality assessment scores using PSQI of 7.6 + 4.0 which show that cancer patients have poor sleep quality. Similar results were obtained from Yennurajalingam (2015) [22] and Alifiyanti et al. It can be said that the results of this study and the previous ones showing the impact of the sleep quality of breast cancer patients undergoing chemotherapy are measured by the same questionnaire and getting a poor sleep quality score of more than 5. Inadequate sleep duration to feel one's best and poor sleep quality after diagnosis were associated with an increased risk of breast cancer progression, particularly for pre-menopausal women [23].

In addition to physical conditions, sleep also affects one's mental state and lack of sleep can affect one's mood [24]. Sleep is one of the most important lifestyles related to multiple health outcomes. Short sleep duration at night, while it increased the breast cancer progression [25].

Weakness from prolonged sleep sometimes has the effects of ego disorganization, hallucinations, and delusions. Besides, people who lack REM sleep show irritability and feel loss of energy and enthusiasm [26]. Factors Affecting Sleep Quality. Decreased sleep quality of breast cancer patients undergoing chemotherapy can be caused by various factors. These factors include age and residence. Residence factors include comfort, with whom the patient lives and other related factors. National Sleep Foundation data in 2010 reported about $67 \%$ of 1508 elderly in America aged 65 years and over experiencing insomnia and as many as $7.3 \%$ of elderly complaining on disturbance of starting and maintaining sleep or insomnia [27]. Rimbawan and Ratep (2016) [28] showed that the prevalence of insomnia varies between $10 \%$ and $40 \%$. Each year it is predicted that around $20-50 \%$ of adults complain on sleep disorders and around $17 \%$ suffer from serious sleep disorders. In
Indonesia, the prevalence of insomnia reaches $10 \%$, which means that 28 million people out of a total of 238 million Indonesians suffer from insomnia.

Aging factors give effect to changes in sleep patterns so that there are some sleep obstacles in old age. Sleep patterns in old age can pose a risk of insomnia, but age growth is not an absolute factor in insomnia in the elderly [29]. Changes in sleep patterns associated with age occur in Sleep Architecture and Circadian Rhythm.

Normal sleep consists of 5 parts, namely levels 1-4 which are NREM sleep and the last level is REM. Parts 1 and 2 are called light sleep, while levels 3 and 4 are called unconscious sleep/slow wave sleep/delta sleep. Increasing age gives impact of changes in sleep levels. In fact, even though they have enough time to sleep, a decline in sleep quality occurs. In the elderly, there is a reduction in sleep level 3, level 4, NREM level, and latent REM, but undergoing an increase in sleep parts 1 and 2 . These changes have several effects namely difficulty to start sleeping, decreased total sleep time, sleep efficiency, transient arousal, and being awakened too early [30].

The center of circadian rhythm regulation is located in the suprachiasmatic nucleus (SCN) in the hypothalamus. Reduction in SCN function is related to increasing age. The elderly who face a decline in SCN function will get the effect like the occurrence of obstacles in the circadian rhythm. One of the symptoms due to circadian rhythm obstacles is the inability to sleep even though there are stimuli. This has some effects on patients who get up and sleep at the wrong time, such as an increased risk of insomnia and an increase in sleep frequency [30].

In general, the overall sleep time of the elderly is almost the same as young adults. Circadian rhythms of sleep and waking up of the elderly are also often constrained. The elderly biological clock is shorter and the sleep phase is more advanced. Elderly often wake up at night so that the effects of fatigue, sleepiness, and easily falling asleep during the day. Therefore, increasing age is also associated with a tendency to sleep and wake up earlier [31].

It is also supported by Sumirta and Laraswati [32] that of 14 respondents, those with the highest category of insomnia were 8 people $(57.1 \%)$ aged $55-74$ years. The results of this study are supported by Darmojo's theory (2005) [30] that age is one of the factors that can have an impact on one's health. This is caused by the cells and organs of the body that has experienced deterioration in function along with the increasing age. As with normal patterns that begin to change with age, it is due to nerve reduction involving sleep waves due to central nervous system deficits that cause reduced reaction to extrinsic alarms and biorhythm dysfunction and reduced release of the substance melatonin [33]. 
In addition, anxiety factors such as excessive feelings of anxiety that leads to depression also have an impact on the sleep quality of cancer patients undergoing chemotherapy. This anxiety condition causes blood norepinephrine levels to increase through stimulation of the sympathetic nervous system. This situation causes a reduction in NREM level 4 sleep cycle and REM sleep, and being awakened while sleeping [33]. It is in accordance with Oetami et al. [34] that the anxiety variable felt by respondents the most was worrying about considering the treatment effect $(84.0 \%)$ of 25 respondents. One informant revealed that he felt anxious because he felt sick and scared because the illness he was suffering was a deadly disease so the effects of the anxiety felt were troublesome to sleep.

Purwati et al. [35] showed that of the 40 female respondents with breast cancer, the majority of respondents in this study had poor sleep quality, as many as 28 respondents (70\%). It was seen during the research that many respondents looked lethargic. They said that it was difficult to sleep and occasionally woke up at night because they were anxious about the current illness and they also complained about the difficulty of adapting to hospital conditions that made it harder to start sleeping. This has an impact on the relationship between the level of anxiety and poor sleep quality. It is because anxiety is higher at night when the situation is quiet which makes respondents often remember the disease being suffered. It is what affects the respondent with difficulty to start sleeping and with occasionally waking up at night. Researchers found that all respondents said that occasionally woke up at night and it was difficult to start sleeping. One of the factors that caused respondents to have difficulty to start sleeping was because they felt anxious. This is also supported by the results of Hananta's research (2014) [36] stating that the prevalence of sleep disorders experienced by breast cancer patients was $67.1 \%$. Cancer patients who face depression are 4.4 times more likely to get sleep disorders than those without depression.

The environmental conditions in which the patients rest also greatly affect the quality of their sleep. Matters relating to whom they live with or the condition of the place of residence itself, such as the ambient temperature which is less calm and the absence of ventilation, can affect their sleep, lighting, room or layout of the room, and also the sound or noise around them. For example, patients treated in hospitals may have different quality of sleep with patients treated at home. Bukit's research (2005) shows that in general $(77 \%)$ the poor quality of patients' sleep is in hospitals. The analysis of paired t-test results in the data was that there was a significant difference, namely sleep quality in hospitals is worse than that of at home $(p<0.001)[7]$.

Very bright lights can cause sleep difficulty for someone. The light effect has the effect of hormone melatonin. The hormone is produced by the pineal gland which is closely located to the human brain, and it is very important for better sleep quality. The body that is exposed to light can suppress the production of melatonin. Light waves can enter the eyelids and then be received by the retina and the lens of the eye so that it will stimulate the brain's activity to work and process incoming information [37].

Sound affects sleep. Someone needs calmness to sleep and to avoid noise. The atmosphere of the surroundings originating from radio or television that has high volume, noise, vehicle noise, and so on can stimulate to the sense of hearing. Then, this sound is captured by the brain so that it will cause discomfort, ultimately giving the effect of being awake [38]. Noise that someone complains about indicates that the sound (from various sources) has exceeded the hearing threshold (level> $40 \mathrm{~dB}$ ), including the sound of the telephone, the doorbell, medical instruments, and the activities of the health team [39]. In addition, hospital treatment affects on patients' anxiety and depression due to worry about disease conditions, medical costs, and medical procedures [7].

In addition to the various factors mentioned above, the pain factor from the effect of therapy or chemotherapy felt by the patient also greatly affects the quality of sleep. Pain can cause sleep problems in breast cancer patients and it can be proven in this study. Some research results, reinforcing the statement, found that sleep disorders were experienced by respondents related to decreased sleep due to neuropathic pain. There are two main causes of pain, namely the development of the disease and the side effects of treatment. The development of the disease can cause pain in the bones and nerves, while treatment related side effects such as mucositis and peripheral neuropathy, can also provide pain effects [39]. Chemotherapy often provides undesirable side effects for patients such as hair loss, blackened skin, nausea, vomiting, blood cell disorders, tingling, numbness, and other peripheral nerve disorders. These side effects often disrupt the sleep pattern of patients [39].

\section{Conclusion}

Breast cancer patients undergoing chemotherapy have poor sleep quality and the factors associated with sleep quality are age and people that the respondents live with.

\section{Acknowledgments}

The researchers are much obliged to Director of the Djojonegoro Temanggung Regional General Hospital for giving permission to conduct this research. 


\section{References}

1. Anggraini D, Semiarty R, Rasyid R, Khambri D. Factors that affect the quality of life of breast cancer sufferers in the city of Padang. J Endurance. 2018;3(3):562-7. https://doi. org/10.22216/jen.v3i3.3094

2. Mulyani NS, Nuryani SS. Kanker Payudara dan Penyakit Menular Seksual Pada Kehamilan. $1^{\text {st }}$ ed. Yogyakarta: Nuha Medika; 2013.

3. American Cancer Society. Cancer Facts and Figures. The Society; 2017. https://doi.org/10.1080/15398285.2012.701177

4. Arruebo M, Vilaboa N, Sáez-Gutierrez B, Lambea J, Tres A, Valladares $\mathrm{M}$, et al. Assessment of the evolution of cancer treatment therapies. Cancers (Basel). 2011;3(3):3279-330. https://doi.org/10.3390/cancers3033279

PMid:24212956

5. Zhang J, Zhou $Y$, Feng Z, Xu Y, Zeng G. Longitudinal trends in anxiety, depression, and quality of life during different intermittent periods of adjuvant breast cancer chemotherapy. Cancer Nurs. 2018;41(1):62-8. https://doi.org/10.1097/ ncc. 0000000000000451

PMid:27922916

6. Wesselius HM, van den Ende ES, Alsma J, Ter Maaten JC, Schuit S, Stassen PM, et al. Quality and quantity of sleep and factors associated with sleep disturbance in hospitalized patients. JAMA Intern Med. 2018;178(9):1201-8. https://doi. org/10.1001/jamainternmed.2018.2669

PMid:30014139

7. Alifiyanti D, Hermayanti $Y$, Setyorini D. The sleep quality of breast cancer patients based on the therapy given at RSUP DR. Hasan Sadikin Bandung. J Pendidikan Keperawatan Indones. 2017;3(1):115-25. https://doi.org/10.17509/jpki.v3i2.9418

8. Imanian M, Imanian M, Karimyar M. Sleep quality and fatigue among breast cancer patients undergoing chemotherapy. Int $J$ Hematol Oncol Stem Cell Res. 2019;13(4):196-200. https://doi. org/10.18502/ijhoscr.v13i4.1894

PMid:31871594

9. Tian J, Chen GL, Zhang HR. Sleep status of cervical cancer patients and predictors of poor sleep quality during adjuvant therapy. Support Care Cancer. 2015;23(5):1401-8. https://doi. org/10.1007/s00520-014-2493-8 PMid:25370891

10. Budhrani PH, Lengacher CA, Kip K, Tofthagen C, Jim H. An integrative review of subjective and objective measures of sleep disturbances in breast cancer survivors. Clin J Oncol Nurs. 2015;19(2):185-91. https://doi.org/10.1188/15.cjon.185-191 PMid:25840384

11. Kurniyawan EH. Murottal Al-Quran Therapy to Increase Sleep Quality in Nursing Students, UNEJ E-Proceeding; 2018. p. 7-14. Available from: https://www.jurnal.unej.ac.id/index.php/ prosiding/article/view/7181. [Last accessed on 2020 May 25].

12. Al-Zalabani $\mathrm{AH}$, Alharbi $\mathrm{KD}$, Fallatah $\mathrm{NI}$, Alqabshawi $\mathrm{RI}$ Al-Zalabani AA, Alghamdi SM. Breast cancer knowledge and screening practice and barriers among women in Madinah, Saudi Arabia. J Cancer Educ. 2018;33(1):201-7. https://doi. org/10.1007/s13187-016-1057-7

PMid:27271153

13. George GC, Iwuanyanwu EC, Anderson KO, YusufA, Zinner RG, Piha-Paul SA, et al. Sleep quality and its association with fatigue, symptom burden, and mood in patients with advanced cancer in a clinic for early-phase oncology clinical trials. Cancer. 2016;122(21):3401-9. https://doi.org/10.1002/cncr.30182 PMid:27412379

14. Maas JB. Power Sleep: Kiat-Kiat Sehat Untuk Mencapai Kondisi dan Prestasi Puncak. Bandung: Kaifa; 2002.

15. Ummah M. Hubungan Antara Stres Akademik Dengan Kualitas Tidur Pada Mahasiswa Pondok Pesantren, Doctoral dissertation, Universitas Mercu Buana Yogyakarta; 2017. https://doi.org/10.33757/jik.v1i1.22

16. Cho Y, Ryu SH, Lee BR, Kim KH, Lee E, Choi J. Effects of artificial light at night on human health: A literature review of observational and experimental studies applied to exposure assessment. Chronobiol Int. 2015;32(9):1294-310. https://doi. org/10.3109/07420528.2015.1073158 PMid:26375320

17. Shen J, Tower J. Effects of light on aging and longevity Ageing Res Rev. 2019;53:100913. https://doi.org/10.1016/j. arr.2019.100913

PMid:31154014

18. Riset Kesehatan Dasar (Riskesdas). Badan Penelitian dan Pengembangan Kesehatan Kementerian RI tahun 2018; 2018. https://doi.org/10.22435/jpppk.v2i3.1133

19. Nurzallah AP. Pengaruh Pemberian Terapi Musik Klasik Mozart Terhadap Waktu Pulih Sadar Pasien Kanker Payudara Dengan Anestesi General di RSUD Dr. Moewardi Surakarta, Surakarta; 2015. https://doi.org/10.29238/caring.v7i2.357

20. Reynolds-Cowie P, Fleming L. Living with persistent insomnia after cancer: A qualitative analysis of impact and management. Br J Health Psychol. 2020;26(1):33-49. https://doi.org/10.1111/ bjhp.12446

21. Winoto A, Kusnanto K, Sajidin M. The role of family support for fulfilling the sleep needs of hemodialysis patients. J IImiah Keperawatan. 2020;6(1):80-6. https://doi.org/10.33023/jikep. v6i1.445

22. Yennurajalingam $S$, Balachandran $D$, Cardozo SL, Berg EA Chisholm GB, Reddy A, et al. Patient-reported sleep disturbance in advanced cancer: Frequency, predictors and screening performance of the Edmonton symptom assessment system sleep item. BMJ Support Palliat Care. 2017;7(3):274-80. https:// doi.org/10.1136/bmjspcare-2015-000847

\section{PMid:26475092}

23. Liang $Z Z$, Zhang $Y X$, Lin $Y$, Liu $Q$, Xie XM, Tang LY, et al. Joint effects of multiple sleep characteristics on breast cancer progression by menopausal status. Sleep Med. 2019;54:153-8. https://doi.org/10.1016/j.sleep.2018.10.025 PMid:30580187

24. Webb JT, Amend ER, Webb N. Misdiagnosis and Dua Diagnoses of Gifted Children and Adults. Scottsdale: Great Potential Press, Inc.; 2001.

25. Richmond RC, Anderson EL, Dashti HS, Jones SE, Lane JM, Strand LB, et al. Investigating causal relations between sleep traits and risk of breast cancer in women: mendelian randomisation study. BMJ. 2019;365:I2327. https://doi. org/10.1136/bmj.12327

PMid:31243001

26. Kaplan HI, Sadock BJ, Grebb JA. Sinopsis psikiatri. In Terjemahan Widjaja Kusuma. $7^{\text {th }}$ ed., Vol. 1. Jakarta: Binarupa Aksara; 1997. p. 86-108.

27. Anonim. National Sleep Foundation Diunduh Pada; 2010 Available from: https://www.sleepfoundation.org/professionals/ sleep-americar-polls/2010-sleep-and-ethnicity. [Last accessed on 2019 Oct 10].

28. Rimbawan PP, Ratep N. Pravalensi dan korelasi insomnia terhadap kemampuan kognitif remaja usia 15-18 tahun di panti asuhan widhya asih 1 Denpasar. J Med. 2016;5(5):1-8. Available from: https://www.ojs.unud.ac.id/index.php/eum/ article/view/20714. [Last accessed on 2020 May 25].

29. Astuti NM. Penatalaksanaan Insomnia Pada Usia Lanjut (Naskah Publikasi, Universitas Udayana); 2013. Available from: http:// www.academia.edu/download/35088794/5119-8086-1-sm. pdf. 
[Last accessed on 2020 May 25].

30. Darmojo RB. Proses Menua dan Implikasi Kliniknya. Buku Ajar Penyakit Dalam. $5^{\text {th }}$ ed., Vol. 1. Jakarta: Fakultas Kedokteran UI; 2011.

31. Vinayak S, Dehkhoda F, Vinayak R. The effect of music therapy on sleep quality of cancer patients undergoing chemotherapy or radiotherapy:Arandomized control trial. J Soc Sci. 2017;6(4):73443. https://doi.org/10.25255/jss.2017.6.4.734.743

32. Sumirta IN, Laraswati Al. Faktor yang menyebabkan gangguan tidur (insomnia) pada lansia. J Gema Keperawatan. 2015;8(1):20-30. Available from: http://www.poltekkesdenpasar.ac.id/files/jurnal\%20gema\%20keperawatan/juni\%20 $2015 / 1 \% 20$ nengah\%20sumirta.pdf. [Last accessed on 2020 May 25].

33. Ratnasari DR. Gambaran Kualitas Tidur Pada Komunitas Game Online Mahasiswa Teknik Elektro Universitas Diponegoro, Skripsi. Indonesia: Universitas Diponegoro; 2016. https://doi. org/10.32315/sem.1.a055

34. Oetami F, Thaha IL, Wahiduddin W. Analisis Dampak Psikologis Pengobatan Kanker Payudara Di Rs Dr. Wahidin Sudirohusodo Kota Makassar. Naskah Publikasi, Universitas Hasanuddin; 2014. Available from: http://www.repository.unhas.ac.id/ handle/123456789/10727.
35. Purwati P, Ma'rifah AR, Maryati S. The relationship between anxiety levels and sleep quality in breast cancer patients in the Bougenvil RSUD Prof. Dr. Margono Soekarjo Purwokerto. Bhamada. 2016;7(1):1-8. https://doi.org/10.36085/jkmu. v7i1.308.s37

36. Handayani RS, Udani G. Sleep quality and distress in cancer patients undergoing chemotherapy. J IImiah Keperawatan Sai Betik. 2017;12(1):66-72. https://doi.org/10.26630/jkep. v14i1.1000

37. Lai KY, Sarkar C, Ni MY, Cheung LW, Gallacher J, Webster C. Exposure to light at night (LAN) and risk of breast cancer: A systematic review and meta-analysis. Sci Total Environ. 2020;762:143159. https://doi.org/10.1016/j. scitotenv.2020.143159

38. Afshar PF, Bahramnezhad F, Asgari P, Shiri M. Effect of white noise on sleep in patients admitted to a coronary care. J Caring Sci. 2016;5(2):103-9. https://doi.org/10.15171/jcs.2016.011 PMid:27354974

39. Fontes F, Gonçalves M, Pereira S, Lunet N. Neuropathic pain after breast cancer treatment and its impact on sleep quality one year after cancer diagnosis. Breast. 2017;33:125-31. https://doi. org/10.1016/j.breast.2017.03.013

PMid:28384563 